\title{
Neuromediated action of $\beta$-casomorphins on ion transport in rabbit ileum
}

\author{
D. TOMÉ (1), A. BEN MANSOUR, M. HAUTEFEUILLE, \\ Anne-Marie DUMONTIER, J.-F. DESJEUX
}

INSERM U. 290. Hôpital Saint-Lazare,

107 bis, rue du Faubourg-Saint-Denis, 75010 Paris, France.

Summary. $\beta$-casomorphins $\left(\beta-\mathrm{CM}_{\mathrm{s}}\right)$ are opioid peptides derived from milk $\beta$-casein. The $\beta$-casomorphin analog $\beta$-[DAla $\left.{ }^{2,4}, \mathrm{Tyr}^{5}\right] \mathrm{CM}-5-\mathrm{NH}_{2}$ reduced short-circuit current (Isc) and stimulated electrolyte absorption by an opioid effect in rabbit ileum in vitro. This effect was inhibited by $10^{-7} \mathrm{M}$ tetrodotoxin, $10^{-6} \mathrm{M}$ epinephrine and $10^{-5} \mathrm{M}$ naloxone. Atropine in the $10^{-7}-10^{-5} \mathrm{M}$ range and $10^{-5} \mathrm{M}$ hexamethonium did not inhibit the action of the peptide on Isc. In comparison the muscarinic effect of $10^{3} \mathrm{M}$ carbachol was inhibited by atropine in the $10^{8}-10^{5} \mathrm{M}$ range. These results indicate that the action of the $\beta$-casomorphin analog was neuromediated and suggest that this peptide acted on the submucosal plexus located on the blood side of the intestinal epithelium. A physiological role of the food-derived $\beta$ - $\mathrm{CM}_{\mathrm{s}}$ peptides implies the passage of the active sequences from the lumen to the blood side of the intestine.

\section{Introduction.}

$\beta$-casomorphins $\left(\beta-\mathrm{CM}_{\mathrm{s}}\right)$ are opioid peptides derived from cow's milk $\beta$-casein (Brantl et al., 1981). Natural $\beta$ - $\mathrm{CM}_{\mathrm{s}}$, present in the [60-66] fragment of bovine $\beta$-casein, are characterised by the $\mathrm{N}$-terminal amino-acid sequence Tyr-Pro-Phe-Pro of the [60-63] fragment. In addition, $\beta-\mathrm{CM}_{\mathrm{s}}$ analogs are prepared by amino-acid substitution and $\mathrm{C}$-terminal amidation to increase opioid potency (Brantl et al., 1982). The functional significance of the presence of these $\beta-\mathrm{CM}_{\mathrm{s}}$ in milk protein digestion remains uncertain. Nevertheless natural $\beta-\mathrm{CM}_{\mathrm{s}}$ as well as its non-metabolized $\beta-\mathrm{CM}-5$ analog, $\beta$-[DAla $\left.{ }^{2,4}, \mathrm{Tyr}^{5}\right]-\mathrm{CM}-5-\mathrm{NH}_{2}$ (Tyr-DAla-Phe-DAla-Tyr- $\mathrm{NH}_{2}$ ), stimulate electrolyte absorption in rabbit ileum in vitro (Hautefeuille et al., 1986 ; Tomé et al., 1987). The mechanism whereby these $\beta-\mathrm{CM}_{\mathrm{s}}$ influence intestinal ion transport is unknown. So far, no opioid receptors have been located on the enterocyte membrane and it has been proposed that endogenous opiates act indirectly on intestinal epithelium by

(1) Correspondence: Daniel TOME. 
modulating the release of neurotransmitters by the intrinsic nervous system of intestine (Binder et al., 1984 ; Cooke, 1986 ; Dobbins et al., 1980 ; Cooke et al., 1983 ; Kachur et al., 1980).

The present study was done to determine whether $\beta-\mathrm{CM}_{\mathrm{s}}$ have a direct or indirect action on enterocyte membrane and also which kind of mediation is implicated in this action. Using rabbit ileum mounted in an Ussing chamber, we tested, in vitro, the modification of the action of $\beta-\mathrm{CM}$ analog, $\beta$-[DAla ${ }^{2.4}$, $\mathrm{Tyr}^{5}$ ] $-\mathrm{CM}-5-\mathrm{NH}_{2}$, on intestinal ion transport by a nerve conduction blocking agent (tetrodotoxin), a muscarinic agonist (atropine), a nicotinic ganglionic blocking agent (hexamethonium) and an adrenergic agonist (epinephrine). Because short-circuit current (Isc) is a convenient indicator of the opiate effect on active electrolyte transport through the small intestine it was used to measure these modifications (Kachur et al., 1980). The results show that the action of the $\beta$-CM analog was neuromediated.

\section{Materials and methods.}

1. Experimental protocol. - Stripped tissues of rabbit ileum were studied using a modified version of the Ussing apparatus (Tai et al., 1981). Non-fasting male New-Zealand white rabbits weighing 2.5 to $3.5 \mathrm{~kg}$ were killed by intravenous injection of pentobarbital sodium. Segments of distal ileum were removed, rinsed of intestinal contents, and bathed in oxygenated cold Ringer solution. The serosal and external muscular layers were stripped with fine forceps and the tissue was opened along the mesenteric border. This preparation included the epithelial layer that transports electrolytes and the intrinsic nervous system in the underlying submucosa. Pieces of stripped tissue were mounted as a flat sheet between the two halves of a lucite chamber (exposed area $1.13 \mathrm{~cm}^{2}$ ) and bathed on each side, at a temperature of $37^{\circ} \mathrm{C}$, by $10 \mathrm{ml}$ of isotonic Ringer solution containing (in $\mathrm{mM}$ ) $140 \mathrm{Na}^{+}, 5.2 \mathrm{~K}^{+}, 120 \mathrm{Cl}^{-}, 25 \mathrm{HCO}_{3}, 1.2 \mathrm{Ca}^{2+}, 2.4 \mathrm{HPO}_{4^{2}}, 0.4 \mathrm{H}_{2} \mathrm{PO}_{4}, 1.2 \mathrm{Mg}^{2+}$, and 10 glucose $\left(\mathrm{pH} 7.4\right.$ with $95 \% \mathrm{O}_{2}$ and $5 \% \mathrm{CO}_{2}$ ). The mucosal and serosal sides of the tissue were then bathed separately by the mucosal and serosal reservoir, respectively. The spontaneous transmucosal electrical potential difference (PD) was measured via Ringer solution in $4 \%$ agar bridges placed on each side of the tissue and adapted to calomel half-cells connected to a high impedance voltmeter. PD was short-circuited throughout the experiment by a short-circuit current (ISc) via Ringer solution in $4 \%$ agar bridges placed in each reservoir, adapted to $\mathrm{Ag} / \mathrm{AgCl}$ electrodes and connected to an automatic voltage clamp (WPI, New Haven, CT, USA). Delivered Isc was corrected for fluid resistance and continuously monitored on a chart recorder. Isc is a measure of ionic movements across the epithelium, and a modification of Isc expresses a modification of ion transport. For instance, a decrease of Isc indicates either anion absorption or cation secretion. Every $50 \mathrm{sec}$ the tissue was automatically clamped at $\pm 1 \mathrm{mV}$ to calculate the electrical conductance $(\mathrm{G})$ of the tissue. 
2. Measurement of mucosal transport. - After checking the stability of the electrical parameters for at least $15 \mathrm{~min}$, the compounds to be tested were added to the serosal reservoir only and the change produced in Isc $(\Delta \mathrm{Isc})$ relative to the base line value was considered to be a measurement of mucosal ion transport modification.

Treatment was at a concentration of $10^{5} \mathrm{M}$ for naloxone and $10^{-6} \mathrm{M}$ for epinephrine (Dobbins et al., 1980), $10^{-9}-10^{3} \mathrm{M}$ for atropine (Hubel, 1978), $10^{-5} \mathrm{M}$ for hexamethonium (HXM) (Hubel, 1984) and $10^{4} \mathrm{M}$ for $\beta-\mathrm{CM}-5$ and $\beta$-[DAla $\left.{ }^{2,4}, \mathrm{Tyr}^{5}\right] \mathrm{CM}-5-\mathrm{NH}_{2}$ (Hautefeuille et al., 1986 ; Tomé et al., 1987). In the stripped ileum preparation, intrinsic innervation was inhibited by the addition of neurotoxin tetrodotoxin (TTX) at a concentration of $10^{-7} \mathrm{M}$ (Hubel, 1984). Carbachol $10^{3} \mathrm{M}$ has been shown to cause an initial rise in Isc followed by a secondary drop to below the basal value (Tapper et al., 1978); the initial rise in Isc $(\Delta \mid \mathrm{sc})$ is due to muscarinic stimulation and was considered as a measurement of muscarinic effect. In each case, the drug was added after a new steady state had been reached.

The natural $\beta$-casomorphin-5 (present in the amino-acid sequence of milk $\beta$-casein), $\beta$-CM-5 (Tyr-Pro-Phe-Pro-Gly), and its non-metabolized analog, $\beta$-[DAla $\left.{ }^{2,4}, \mathrm{Tyr}^{5}\right] \mathrm{CM}-5-\mathrm{NH}_{2}$ (Tyr-DAla-Phe-DAla-Tyr- $\mathrm{NH}_{2}$ ), were purchased from Bachem Biochem (Switzerland); their purity was controlled by HPLC. Carbachol, atropine, epinephrine, hexamethonium and tetrodotoxin were purchased from Sigma (Mo).

The results are expressed as means $\pm \mathrm{SE}$, and statistical analysis was performed using Student's t-test.

\section{Results.}

As shown in figure 1, serosal addition of $10^{4} \mathrm{M} \beta-\mathrm{CM}-5$ or $\beta$ - [DAla $\left.{ }^{2,4}, \mathrm{Tyr}^{5}\right]$ $\mathrm{CM}-5-\mathrm{NH}_{2}$ caused a naloxone-reversible reduction of Isc. The response of the non-metabolized analog was however more stable and it was used for further experiments. Serosal addition of $10^{-7} \mathrm{M}$ TTX also produced a reduction in Isc ; in that case, the tissue did not respond further to addition of $10^{-4} \mathrm{M} \beta$-[DAla ${ }^{2,4}$, $\left.\mathrm{Tyr}^{5}\right] \mathrm{CM}-5-\mathrm{NH}_{2}$ and $10^{-5} \mathrm{M}$ naloxone (fig. 2). Electrical conductance did not vary with the experimental conditions during the $25 \mathrm{~min}$ period of observation.

Serosal addition of atropine to the ileum did not modify basal Isc in the $10^{-7}-10^{-5} \mathrm{M}$ range or cause a dose-dependant reduction of basal Isc in the $10^{-5}-10^{-3} \mathrm{M}$ range (fig. 3 ). The decrease in Isc induced by $10^{-4} \mathrm{M} \beta$-[DAla ${ }^{2,4}$, $\left.\mathrm{Tyr}^{5}\right] \mathrm{CM}-5-\mathrm{NH}_{2}$ was unaffected by prior addition of atropine in the $10^{-7}-10^{-5} \mathrm{M}$ range but was inhibited in a dose-dependant manner by atropine in the $10^{5}-10^{-3} \mathrm{M}$ range (fig. 4A). For comparison the muscarinic effect on Isc caused by $10^{-3} \mathrm{M}$ carbachol was inhibited in a dose-dependant manner by prior addition of atropine in the $10^{-8}-10^{-4} \mathrm{M}$ range (fig. 4B). It appeared that atropine at a concentration of $10^{-5} \mathrm{M}$ (which almost completely inhibited the effect of $10^{3} \mathrm{M}$ carbachol) had no effect against the action of $10^{4} \mathrm{M} \beta$-[DAla $\left.{ }^{2,4}, \mathrm{Tyr}^{5}\right] \mathrm{CM}-5$ $-\mathrm{NH}_{2}$. No significant change in electrical conductance was observed. 

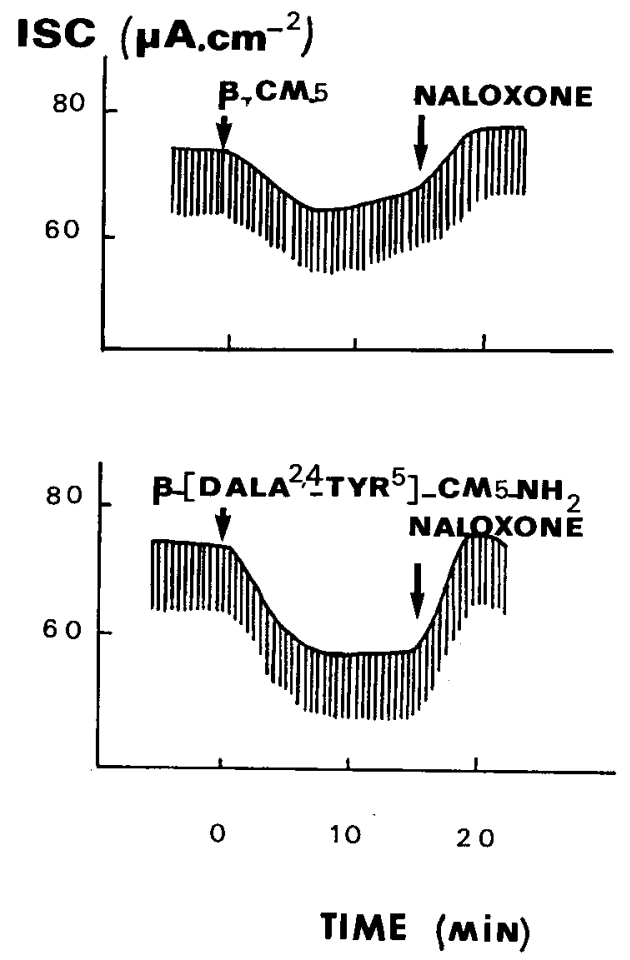

FIG. 1. - Typical recording of electrical response to addition of $10^{-4} \mathrm{M} \beta-C M-5$ or $\beta-\left[D a a^{2,4}, T_{y r}^{5}\right]-C M-5-\mathrm{NH}_{2}$ to serosal side of rabbit ileum in an Ussing chamber followed by serosal addition of $10^{-5} \mathrm{M}$ naloxone. Short-circuit current is expressed in $\mu \mathrm{A} / \mathrm{cm}^{2}$. Every $30 \mathrm{sec}$ the tissue was automatically clamped to $1 \mathrm{mV}$ to monitor electrical conductance represented by the vertical lines.

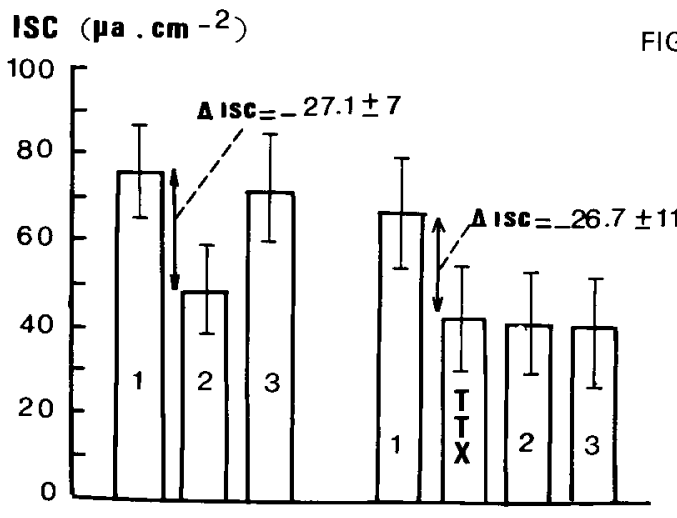

A
B
FIG. 2.- Effect on basal short-circuit current (Isc) (1) of adding the two following sequences of compounds to the serosal side of rabbit ileum: (A) $10^{4} \mathrm{M} \beta-\left[D A / a^{2,4}\right.$, $\mathrm{Tyr}^{5}$ ] CM-5- $\mathrm{NH}_{3}$ (2) and $10^{5} \mathrm{M}$ naxolone (3): (B) $10^{-3} \mathrm{M}$ tetrodotoxin (TTX), $10^{4} \mathrm{M} \beta-\left[D A / a^{2.4}, T y r^{5}\right] \quad \mathrm{CM}-5-\mathrm{NH}_{2}(2)$ and $10^{5} \mathrm{M}$ naloxone (3). In each case basal Isc (1) and Isc after addition of TTX, $\beta$-[DAla ${ }^{2,4}$, $\mathrm{Tyr}^{5}$ ] $\mathrm{CM}-5-\mathrm{NH}_{2}(2)$ and naloxone (3) were recorded after the steady state was reached. Each value represents the mean \pm SE of 10 pieces of tissue. Statistical analysis: A - (2) significantly different from (1) and (3) $(p<0.005)$; $B-(T T X)$ significantly different from (1) $(p<0.005)$; (2), (3) not significantly different from TTX. 
FIG. 3. - Effect on short-circuit current (Isc) of the addition of increasing concentrations of atropine to the serosal side of rabbit ileum. The maximum decrease on Isc was used for calculation. The number of tissues studied at each concentration is shown in parenthesis.
FIG. 4. - Effect of the addition of increasing concentrations of atropine to the serosal side of rabbit ileum :- (A) on the decrease in short-circuit current ( $\Delta \mathrm{Isc}$ ) produced by the subsequent addition of $10^{-4} \mathrm{M} \beta$ $\left[\mathrm{DAla}{ }^{2,4}, \mathrm{Tyr}^{5}\right] \mathrm{CM}-5-\mathrm{NH}_{2} ;-(\mathrm{B})$ on the initial rise in $/ s c(\Delta \mathrm{lsc})$ caused by the subsequent addition of $10^{-3} \mathrm{M}$ carbachol. Each point represents the mean \pm SE of at least 6 pieces of tissue.

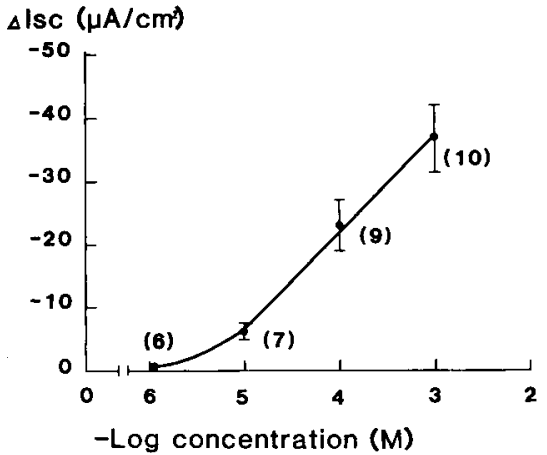

$\Delta \operatorname{ISC}\left(\mu \mathrm{cm} \mathrm{cm}^{2}\right)$

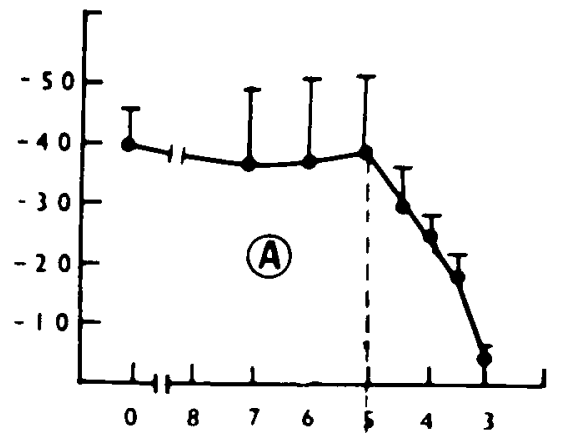

$\triangle$ ISC $\left(\mu A \mathrm{~cm}^{-2}\right)$

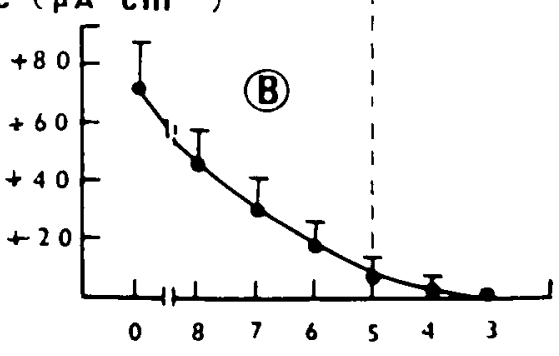

atropine - Log concentration (M) 
As reported in table 1 a complete inhibition of the action of the $\beta$ - $\mathrm{CM}$ analog was obtained by prior addition of either $10^{-5} \mathrm{M}$ naloxone or $10^{6} \mathrm{M}$ epinephrine but was unaffected by $10^{-5} \mathrm{M} \mathrm{HXM}$. Tissue pretreatment by $10^{4} \mathrm{M} \beta$-[DAla ${ }^{2,4}$, Tyr ${ }^{5}$ ] CM-5- $\mathrm{NH}_{2}$ significantly reduced the decrease in Isc produced by $10^{-6} \mathrm{M}$ epinephrine but did not suppress this effect.

TABLE 1

Decrease in short-circuit current ( $\Delta \mathrm{Isc})$ produced by the addition of $10^{4} \mathrm{M} \beta-\left[D A / a^{2.4}, T y r^{5}\right]$ $\mathrm{CM}-5-\mathrm{NH}_{2}$, or $10^{-6} \mathrm{M}$ epinephrine to the serosal side of rabbit ileum control or pretreated by different drugs. Results are expressed in $\mu \mathrm{A} / \mathrm{cm}^{2}$ of tissue area. Each value represents the mean $\pm \mathrm{SE}$ of 10 pieces of tissue. (a) significantly different from the control ( $p<0.01$ ); (b) not significantly different from the control.

\begin{tabular}{|c|c|c|c|c|c|}
\hline \multirow[b]{2}{*}{$\Delta \mathrm{lsc}\left(\mu \mathrm{A} / \mathrm{cm}^{2}\right)$} & \multirow{2}{*}{$\begin{array}{l}\text { Control } \\
\text { Tissue }\end{array}$} & \multicolumn{4}{|c|}{ Tissue pretreated by } \\
\hline & & $\begin{array}{c}\beta-\left[\mathrm{DAla}^{2,4}, \mathrm{Tyr}^{5}\right] \\
\mathrm{CM}-5-\mathrm{NH}_{2} \\
10^{-4} \mathrm{M}\end{array}$ & $\begin{array}{c}\text { Naloxone } \\
10^{5} \mathrm{M}\end{array}$ & $\begin{array}{c}\text { Epinephrine } \\
10^{6} \mathrm{M}\end{array}$ & $\begin{array}{c}\operatorname{HMX} \\
10^{5} \mathrm{M}\end{array}$ \\
\hline & & & (a) & (a) & (b) \\
\hline \multirow[t]{2}{*}{$\begin{array}{l}\beta-\left[\mathrm{DAla}^{2,4}, \mathrm{Tyr}^{5}\right] \\
\mathrm{CM}-5-\mathrm{NH}_{2}\left(10^{4} \mathrm{M}\right)\end{array}$} & $\begin{array}{l}-20.7 \\
\pm \quad 8\end{array}$ & - & $\begin{array}{r}-0.8 \\
\pm 0.5\end{array}$ & $\begin{array}{l}-2.2 \\
\pm 1.2\end{array}$ & $\begin{array}{l}-23.4 \\
\pm 10.2\end{array}$ \\
\hline & & (a) & & & \\
\hline $\begin{array}{l}\text { Epinephrine } \\
\left(10^{6} \mathrm{M}\right)\end{array}$ & $\begin{array}{l}-38.1 \\
\pm \quad 9.1\end{array}$ & $\begin{array}{l}-19.2 \\
\pm \quad 9.3\end{array}$ & - & - & - \\
\hline
\end{tabular}

\section{Discussion.}

As previously shown natural $\beta$-CM- 5 as well as the $\beta$-CM analog $\left[\beta\right.$-DAla ${ }^{2.4}$, $\left.\mathrm{Tyr}^{5}\right] \mathrm{CM}-5-\mathrm{NH}_{2}$ exhibited functional similarities with enkephalins because they reduced Isc on isolated rabbit ileum by naloxone-reversible action (Hautefeuille et al., 1986 ; Tomé et al., 1987). The ionic significance of this decrease on Isc produced by opiates is still not clear since ionic flux measurements indicate stimulation of neutral $\mathrm{NaCl}$ absorption, with a net $\mathrm{Cl}$ absorption not statistically greater than net $\mathrm{Na}$ absorption (Dobbins et al., 1980 ; Hautefeuille et al., 1986). However, a strong linear correlation was reported between the decrease in Isc and the increase in net $\mathrm{Cl}$ absorption produced by DAla-metenkephalin amide, suggesting that $\mathrm{Cl}$ absorption accounted in part for the decrease in Isc (Dobbins et al., 1980). This effect could be in relation with the cation selectivity of the tight junctions that permit $\mathrm{Na}$, but not $\mathrm{Cl}$, to diffuse back into the mucosal solution; it could also be related with a modification in $\mathrm{Cl}$ permeability at the brush-border, resulting in a decrease in $\mathrm{Cl}$ secretion (Dobbins et al., 1980; McKay et al., 1981).

The present results indicate that the $\beta$ - $\mathrm{CM}$ analog acts through a neuromediated mechanism since its action is inhibited by TTX, a neurotoxin which specifically blocks the propagation of the action potential in excitable tissues in intestinal submucosa (Hubel, 1976). This finding is consistent with other results 


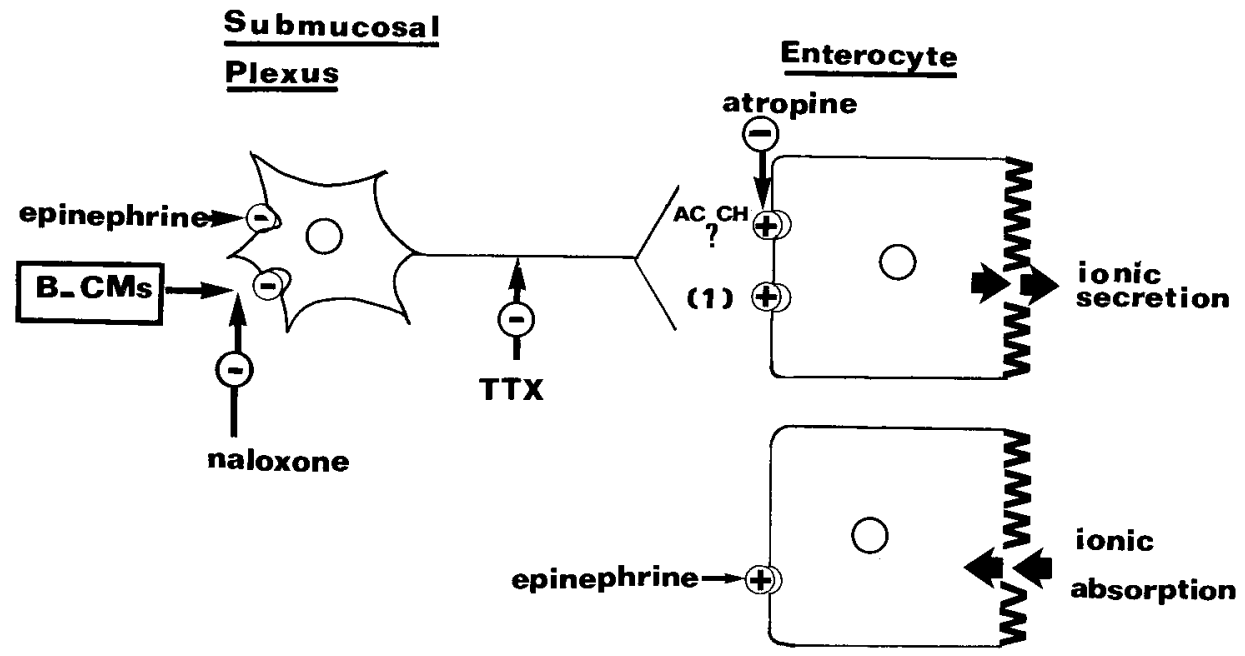

\section{AC $\mathrm{CH} \rightarrow$ acetyl choline \\ (1) $\rightarrow$ unidentified \\ secretory neurotransmitters}

FIG. 5. - Mode/ illustrating the effect of $\beta-C M_{s}$ on electrolyte transport in the rabbit ileum. The release from the enteric nervous system of secretory neurotransmitters acting on receptors located on enterocytes induces electrogenic ionic secretory tone. $\beta-\mathrm{CM}_{\mathrm{s}}$ acts on opioid receptors located in the enteric nervous system and inhibits this secretory tone; this inhibition reduces basal short-circuit current (Isc). Naloxone inhibits the action of $\beta-\mathrm{CM}_{\mathrm{s}}$ on opioid receptors. TTX blocks the propagation of action potential. Epinephrine has the same inhibitory effect as $\beta-\mathrm{CM}_{\mathrm{s}}$ on the enteric nervous system but also acts directly on adrenergic receptors located on enterocytes and induces electrogenic ionic absorption. Acetylcholine is probably not the neurotransmitter involved in the secrtory tone inhibited by $\beta-\mathrm{CM}_{\mathrm{s}}$; this neurotransmitter (1) is still not identified.

indicating that opiate receptors are not present on the enterocyte membrane of rabbit intestine, but are mainly located in submucosal and myenteric plexuses (Binder et al., 1984 ; Dobbins et al., 1980 ; Hubel, 1976). Thus the $\beta$-CM analog acts by modulating the release from intramural nerves of secondary neurotransmitters acting on enterocyte. Since this analog stimulates electrolyte absorption, its action either stimulates the release of antisecretory neurotransmitters, or inhibits the release of secretory agents. It is known that intestinal absorption of electrolytes is regulated by adrenergic and cholinergic (Chang et al., 1982 ; Cooke et al., 1983; Cooke, 1986) together with local non-adrenergic, non-cholinergic enteric nerves (Cooke, 1986). In the present study the interaction of the $\beta$-CM analog with adrenergic and cholinergic nerves was evaluated.

Adrenergic receptors are present both in enterocyte and in submucosal plexuses (Chang et al., 1982 ; Cooke, 1986 ; Keast et al., 1986). This leads to two actions of the adrenergic agonist epinephrine : a direct action on the enterocyte that stimulates electrolyte absorption and an indirect action on submucosal neurons that inhibits the release, from intramural nerves, of neurotransmitters 
which have a secretory effect on the enterocytes (Hubel, 1976, 1985 ; Cooke, 1986 ; Keast et al., 1986). In the present experiment the $\beta$-CM analog effect was entirely inhibited by epinephrine, whereas epinephrine effect was only partially $(50 \%)$ reduced by the peptide. This result, together with the finding that the action of the peptide was neuromediated, suggests that epinephrine and $\beta$-[DAla $\left.{ }^{2,4}, \mathrm{Tyr}^{5}\right] \mathrm{CM}-5-\mathrm{NH}_{2}$ have the same indirect action on submucosal plexus. Thus the $\beta$-CM analog probably acts on submucosal neurons by an inhibitory input; the peptide, like epinephrine, would inhibit the release, from intramural nerves, of secretory neurotransmitters acting on enterocytes.

As opiates are known to inhibit the release of acetylcholine at different levels, the hypothesis that $\beta-\mathrm{CM}_{\mathrm{s}}$ inhibits the release of acetylcholine from intramural nerves on the intestine has been tested. Cholinergic receptors are present both in submucosal plexus and in enterocytes (Cooke, 1986 ; Cowie et al., 1978 ; Furness et al., 1978). The nicotinic cholinergic receptors in submucosal plexus are antagonized by $10^{-5} \mathrm{M} \mathrm{HXM} \mathrm{(Hubel,} \mathrm{1984)} \mathrm{and} \mathrm{the} \mathrm{muscarinic} \mathrm{cholinergic}$ receptors in enterocytes are antagonized by $10^{-5}-10^{-6} \mathrm{M}$ atropine, as observed for the inhibition of the muscarinic effect of carbachol. In the present study $10^{-5} \mathrm{M}$ $\mathrm{HXM}$ had no effect on the action of $\beta$-[DAla $\left.{ }^{2,4}, \mathrm{Tyr}^{5}\right]-\mathrm{CM}-5-\mathrm{NH}_{2}$, indicating that cholinergic nicotinic ganglionic transmission was not implicated in the effect of the peptide on submucosal neurons. The inability of atropine $10^{-6} \mathrm{M}$ to inhibit the action of the $\beta$-CM analog, implies that cholinergic muscarinic receptors were not involved in the mediation of the response. In those conditions, the effect of the $\beta$ - CM analog was probably not an inhibition of a cholinergic tone. The existence of such a tone in the rabbit ileum preparation was not demonstrated either since atropine in the $10^{7}-10^{-5} \mathrm{M}$ range had no effect on basal Isc. As a matter of fact, the inhibition of the muscarinic effect of carbachol by $10^{-6} \mathrm{M}$ atropine demonstrates that in those conditions cholinergic muscarinic receptors were blocked. At the high concentration $\left(10^{-3}-10^{-4} \mathrm{M}\right)$ required to reduce Isc and to inhibit the effect of the peptide, atropine cannot be considered to be a specific antagonist of muscarinic receptors (Hubel, 1978) and probably antagonized other receptors.

In conclusion, the effect of the $\beta$ - $\mathrm{CM}$ analog on intestinal ionic transport was inhibited by an opiate antagonist $\left(10^{-5} \mathrm{M}\right.$ naloxone), a nerve conduction blocking agent $\left(10^{-7} \mathrm{M}\right.$ TTX) and an adrenergic agonist $\left(10^{-6} \mathrm{M}\right.$ epinephrine) but was unaffected by cholinergic antagonists ( $\mathrm{HMX} 10^{-5} \mathrm{M}$ and atropine $\left.10^{-5}-10^{-6} \mathrm{M}\right)$. These results strongly suggest that this peptide acts on opiate receptors located on submucosal neurons and inhibits the release, from intramural nerves, of non-cholinergic secretory effector(s) acting on enterocytes (fig. 4). It is of interest to note that a food-derived peptide analog is able to interact with receptors located on the blood side of the intestinal epithelium. This observation indicates that a physiological role of food-derived $\beta$-casomorphins implies the passage of the active sequences from the lumen to the blood side of the epithelium where their receptors are located. These results confirm our previous finding that natural $\beta-\mathrm{CM}_{\mathrm{s}}$, which are degrated by brush-border enzymes, are inactive when added to the mucosal side of the epithelium. The protected analog $\beta$ - [DAla $\left.{ }^{2,4}, \mathrm{Tyr}^{5}\right]-\mathrm{CM}-5-\mathrm{NH}_{2}$, whose proline residues in positions 2 and 4 were replaced by DAla, is resistant to enzymatic attack, crosses the epithelium as the 
intact peptide when added on the luminal side of the epithelium, and is then active on electrolyte transport (29). Further studies are required to determine under what conditions natural $\beta-\mathrm{CM}_{\mathrm{s}}$ could cross the epithelium intact and to identify the mediator(s) implicated in their action on intestinal electrolyte transport.

Recu en décembre 1987. Accepté en avril 1988.

\section{Résumé. L'action des $\beta$-casomorphines sur le transport des électrolytes dans l'iléon de lapin fait intervenir une neurotransmission.}

Les $\beta$-casomorphines $\left(\beta-\mathrm{CM}_{\mathrm{s}}\right)$ sont des peptides opiacés dérivés de la $\beta$-caséine bovine. L'analogue de $\beta$-casomorphine $\beta$ - [DAla $\left.{ }^{2,4}, \mathrm{Tyr}^{5}\right]-\mathrm{CM}-5-\mathrm{NH}_{2}$ réduit le courant de court-circuit (Isc) et stimule l'absorption d'électrolytes sur l'iléon de lapin in vitro. Cet effet est inhibé par la tétrodotoxine $10^{-7} \mathrm{M}$, l'épinéphrine $10^{-6} \mathrm{M}$ et la naloxone $10^{-5} \mathrm{M}$. L'atropine $10^{-5}-10^{-7} \mathrm{M}$ et l'hexamethonium $10^{-5} \mathrm{M}$ ne modifient pas l'action de l'analogue de $\beta$-CM sur Isc. Par contre l'effet muscarinique du carbachol sur Isc est inhibée par l'atropine $10^{-5}-10^{-8} \mathrm{M}$, ce qui indique que l'atropine à cette concentration bloque les récepteurs cholinergiques muscariniques. Ces résultats indiquent que l'action de l'analogue de $\beta$-casomorphine est indirecte. Ce peptide agit probablement sur des récepteurs opiacés situés dans les neurones sous-muqueux en inhibant la libération par les fibres nerveuses effectrices de neurotransmetteurs non cholinergiques à action sécrétoire sur l'entérocyte. Dans ces conditions, un rôle physiologique des casomorphines, peptides d'origine alimentaire, implique l'absorption de ces composés sous forme active à partir de la lumière intestinale pour rejoindre leurs récepteurs placés sur le versant sanguin de l'intestin.

\section{References}

BINDER H. J., LAURENSON J. P., DOBBINS J. W., 1984. Role of opiate receptors in regulation of enkephalin stimulation of active sodium and chloride absorption. Am. J. Physiol., 247. G432-G436.

BRANTL V., TESCHEMACHER H., BLAZIG J., HENSCHEN A., LOTTSPEICH F., 1981. Opioid activities of $\beta$-casomorphins. Life Sci, 28, 1903-1909.

BRANTL V., PFEIFFER A., HERZ A., HENSCHEN A., LOTTSPEICH F., 1982. Antinociceptive potencies of $\beta$-casomorphin analogs as compared to their affinities toward $\mu$ and $\delta$ receptor sites in brain and periphery. Peptides, 3, 793-797.

CHANG E. B., FIELD M., MILLER R. J., 1982. $\alpha_{2}$-adrenergic receptor regulation of ion transport in rabbit ileum. Am. J. Physiol., 242, G237-G242.

COOKE H. J., 1986. Neurobiology of the intestinal mucosa. Gastroenterology, 90, 1057-1081.

COOKE H. J., SHONNARD K., HIGHISON G., WOOD J. D., 1983. Effects of neurotransmitters release on mucosal transport in guinea pig ileum; Am. J. Physiol., 245, G745-G750.

COWIE A. L., KOSTERLITZ H. W., WATERFIELD A. A., 1978. Factors influencing the release of acetylcholine from the myenteric plexus of the ileum of the guinea pig and rabbit. Br. J. Pharmacol., 64, 565-580.

DOBBINS J., RACUSEN L., BINDER H., 1980. Effect of D-alanine methionine enkephalin amide on ion transport in rabbit ileum. J. clin. Invest., 66, 19-28.

FURNESS J. B., COSTA M., ECKENSTEIN F., 1983. Neurones localized with antibodies against choline acetyl transferase in the enteric nervous system. Neurosci. Lett., 40, 105-109.

HAUTEFEUILLE M., BRANTL V., DUMONTIER A. M., DESJEUX J. F., 1986. In vitro effects of $\beta$-casomorphins on ion transport in rabbit ileum. Am. J. Physiol., 250, G92-G97. 
HUBEL K. A., 1976. Intestinal ion transport : effect of norepinephrine, pilocarpine and atropine. Am. J. Physiol., 231, G252-G257.

HUBEL K. A., 1978. The effects of electrical field stimulation and tetrodotoxin on ion transport by isolated rabbit ileum. J. clin. Invest., 62, 1039-1047.

HUBEL K. A., 1984. Electrical stimulus secretion coupling in rabbit ileal mucosa. J. Pharmacol. exp. Ther., 231, 577-582.

HUBEL K. A., 1985. Intestinal nerves and ion transport: stimuli, reflexes, and responses. Am. J. Physiol., 248, G261-G271.

KACHUR J. F., MILLER R. J., FIELD M., 1980. Control of guinea pig intestinal electrolyte secretion by a $\delta$-opiate receptor. Proc. nat. Acad. Sci. USA, 77, 2753-2756.

KEAST J. R., FURNESS J. B., COSTA M., 1986. Effects of noradrenaline and somatostatin on basal and stimulated mucosal ion transport in the guinea-pig small intestine. Naunyn-Schniedeberg's Arch. Pharmacol., 333, 393-399.

McKAY, 1981. Influence of opiates on ion transport across rabbit ileal mucosa. Gastroenterology, 88, 279-284.

TAI Y. H., FESER J. F., MARMANE W. G., DESJEUX J. F., 1981. Antisecretory effects of berberine in rat ileum. Am. J. Physiol., 241. G253-G258.

TAPPER E. J., POWELL D. W., MORRIS S. M., 1978. Cholinergic-adrenergic interactions on intestinal ion transport. Am. J. Physiol, 235, G402-G409.

TOME D., DUMONTIER A. M., HAUTEFEUILLE M., DESJEUX J. F., 1987. Opiate activity and transepithelial passage of intact $\beta$-casomorphins in rabbit ileum. Am. J. Physiol., 253 (Gastrointest. Liver Physiol., 16), G737-G744. 